\title{
Neutralization of murine myeloid-derived suppressor cells enhances the efficacy of a chimeric antigen receptor T-cells directed against pediatric solid tumors
}

\author{
Steven L Highfill, Adrienne H Long, Rimas J Orentas, Crystal L Mackall \\ From Society for Immunotherapy of Cancer 28th Annual Meeting \\ National Harbor, MD, USA. 8-10 November 2013
}

Genetically engineered T-cells that express chimeric antigen receptors (CARs) to directly target tumor-expressed antigens have shown remarkable activity in clinical trials for hematologic malignancies, but remain unproven for the treatment of solid tumors. We find that in addition to its well known high expression in neuroblastoma, the disialoganglioside GD2 is also highly expressed on pediatric sarcomas. Some human sarcoma cell lines have GD2 expression levels equivalent to that of the prototypical neuroblastoma cell line LAN5, and immunohistochemical staining of primary human tumor tissue samples taken from essentially all patients with metastatic osteosarcoma and a subset of patients with alveolar rhabdomyosarcoma demonstrate robust expression of GD2 on the cell surface. Based on these results, we have developed models to test the ability of GD2-CAR T-cells to target and lyse human sarcomas in vitro and in vivo. We find that GD2-CAR modified T-cells induce specific lysis of GD2-expressing solid tumors in vitro even at effector:target ratios as low as 1:1, but fail to induce a significant response in vivo using the same human cell lines. Interestingly, we discovered that the pediatric sarcoma xenografts induce a large expansion of murine CD11b+Gr1+ myeloid-derived suppressor cells (MDSC) that inhibit human $\mathrm{T}$-cell responses in vitro. These results lead us to adopt a combinatorial therapeutic strategy in which we first neutralized the suppressive potential of MDSC by administration of all-trans retinoic acid (ATRA) followed by GD2-CAR therapy. This combinatorial approach results in significant improvements in both overall survival and tumor growth. Given that

Pediatric Oncology Branch, NCl, Bethesda, MD, USA retinoids are already available in the clinic, these results suggest that the effectiveness of CAR T-cell therapy for solid tumors could be enhanced by coadministration of retinoids to modulate the myeloid derived suppressor cells.

Published: 7 November 2013

doi:10.1186/2051-1426-1-S1-P265

Cite this article as: Highfill et al:: Neutralization of murine myeloidderived suppressor cells enhances the efficacy of a chimeric antigen receptor T-cells directed against pediatric solid tumors. Journal for ImmunoTherapy of Cancer 2013 1(Suppl 1):P265.

Submit your next manuscript to BioMed Central and take full advantage of:

- Convenient online submission

- Thorough peer review

- No space constraints or color figure charges

- Immediate publication on acceptance

- Inclusion in PubMed, CAS, Scopus and Google Scholar

- Research which is freely available for redistribution 